\title{
Formation of virus-like particles from human cell lines exclusively expressing Influenza Neuraminidase
}

\author{
JCC Lai ${ }^{*}$, WWL Chan ${ }^{1}$, JM Nicholls², JSM Peiris ${ }^{1,3}$, JM Garcia $^{1}$ \\ From Institut Pasteur International Network Annual Scientific Meeting \\ Hong Kong. 22-23 November 2010
}

\section{Background}

Neuraminidase (NA) is an important viral component of influenza viruses and the target of most effective antiinfluenza drugs in the market. Most of the data on NA function obtained so far has come from using native virions (which imposes bio-safety issues) or from purified NA proteins which may not have the same properties as that on viral surfaces [1]. We have developed virus-like particles (VLPs) containing only the NA, functionally and morphologically similar to the native virions. NAVLPs may be useful in influenza research such as the investigation of the assembly and budding steps in the virus life cycle as this process is still unclear [2-5].

\section{Methods}

In order to determine the minimal set of viral proteins essential for virus budding, 293T cells were transfected with plasmids encoding for the haemagglutinin (HA), NA and matrix (M1) proteins singly, or in combination. VLP released into the culture medium were collected by ultra-centrifugation and their protein composition analyzed by western blotting. Budding of the VLPs were visualized by electron microscopy. Kinetics of the production of VLP containing solely NA was monitored by enzymatic activity assays and western blotting. Physical and functional characterization of the NA-VLP were carried out using (i) sucrose gradient centrifugation, (ii) neuraminidase activity assay, (iii) NA oligomerization analysis, as well as (iv) lectin staining of sialic acid on cell surface. In addition, the effect of NA enzymatic activity on VLP production was investigated by using

${ }^{1}$ HKU-Pasteur Research Centre, Hong Kong, Hong Kong SAR

Full list of author information is available at the end of the article sialidase inhibitor or a point mutation (E262D) in NA that inactivates the catalytic site.

\section{Results}

VLP formation was detected from cells expressing HA and NA alone but not from cells solely expressing M1 showing that HA an NA each contributes to the driving force for virus budding whereas M1 only had a limited contribution. The sialidase inhibitor and E262D point mutation studies showed that the enzymatic activity of $\mathrm{NA}$ is not required in driving virus budding of NA VLPs. However, release of VLP containing HA was completely dependent on sialidase, either as co-expressed NA or added exogenously. NA-VLPs were morphologically similar to influenza virions by electron microscopy and NA on the VLP surface was chemically and functionally comparable to that on infectious virus particles.

\section{Conclusion}

NA plays a key role in virus budding and morphogenesis at least for the N1 subtype that we studied. These NA-VLPs mimic NA from native virions and represents a very useful tool in influenza research [6].

\section{Author details}

${ }^{1} \mathrm{HKU}$-Pasteur Research Centre, Hong Kong, Hong Kong SAR. ${ }^{2}$ Department of Pathology, The University of Hong Kong, Hong Kong SAR. ${ }^{3}$ Department of Microbiology, The University of Hong Kong, Hong Kong SAR.

Published: 10 January 2011

\section{References}

1. Nagai T, Suzuki Y, Yamada H: Comparison of substrate specificities of sialidase activity between purified enzymes from influenza virus $A$ (H1N1 and H3N2 subtypes) and B strains and their original viruses. Biol Pharm Bull 1995, 18:1251-1254. 
2. Gómez-Puertas P, Albo C, Pérez-Pastrana E, Vivo A, Portela A: Influenza virus matrix protein is the major driving force in virus budding. I Virol 2000, 74:11538-11547.

3. Latham T, Galaeza JM: Formation of wild-type and chimeric influenza virus-like particles following simultaneous expression of only four structural proteins. J Virol 2001, 75:6154-6165.

4. Chen BJ, Leser GP, Morita E, Lamb RA: Influenza virus hemagglutinin and neuraminidase, but not the matrix protein, are required for assembly and budding of plasmid-derived virus-like particles. J Virol 2007, 81:7111-7123.

5. Wang D, Harmon A, Jin J, et al: The lack of an inherent membrane targeting signal is responsible for the failure of the matrix (M1) protein of influenza A virus to bud into virus-like particles. J Virol 2010, 84:4673-4681.

6. Lai JC, Chan WL, Kien F, et al: Formation of virus-like particles from human cell lines exclusively expressing influenza neuraminidase. J Gen Virol 2010, 91:2322-2330.

doi:10.1128/JVI.74.24.11538-11547.2000

Cite this article as: Lai et al:: Formation of virus-like particles from human cell lines exclusively expressing Influenza Neuraminidase. BMC Proceedings 2011 5(Suppl 1):P66.

\section{Submit your next manuscript to BioMed Central} and take full advantage of:

- Convenient online submission

- Thorough peer review

- No space constraints or color figure charges

- Immediate publication on acceptance

- Inclusion in PubMed, CAS, Scopus and Google Scholar

- Research which is freely available for redistribution

Submit your manuscript at www.biomedcentral.com/submit 